As-Syifaa Jurnal Farmasi Desember 2020;12(2):144-149.

ISSN : 2502-9444 (electronic); 2085-4714 (printed)

Journal Homepage : http://jurnal.farmasi.umi.ac.id/index.php/as-syifaa

\title{
ISOLASI DAN IDENTIFIKASI FUNGI ENDOFIT BATANG SESURU (Euphorbia antiquorum L.) SEBAGAI PENGHASIL ANTIBAKTERI DENGAN METODE KLT-BIOAUTOGRAFI
}

\author{
Asnita, Rachmat Kosman, Herwin, Ayyub Harly Nurung \\ Fakultas Farmasi Universitas Muslim Indonesia, Makassar \\ Email: asnitaaaa98@gmail.com
}

\begin{abstract}
The research aimed to obtain antibacterial activity of isolate fermentate of endophytic fungi of antique spurge stem (Euphorbia antiquorum L.) on Staphylococcus aureus and Escherichia coli by TLC-Bioautography. The methods used in this research were isolation, purification and isolate screening. The screening results of endophytic fungi isolate of antique spurge stem showed the largest inhibitory zone in preventing both bacteria growth using code IFBS-03 and IFBS-06. The chromatogram profile of antibacterial activity isolate fermentate of the codes IFBS-03 and IFBS-06 showed active spots using TLC-Bioautographic method showed that code IFBS-03 isolate obtained Rf 0.87 and 0.27 values, indicating active spots on Staphylococcus aureus and Escherichia coli. The result of code IFBS-06 isolate obtained $R f 0.83$ value active spots against Staphylococcus aureus and values Rf 0.83 and 0.27 value on Escherichia coli. Based on isolation and identification some chemical components obtained that dietyl ether ekstract of thin layer cromatography obtained chemicals components flavanoid at $\mathrm{Rf} 0.83$ and 0.27 value with reagent Antimo (III) chloride.
\end{abstract}

Key words: Endophytic Fungi of Antique Spurge Stem (Euphorbia antiquorum L.), TLCBioautography, Antibacterial.

\section{PENDAHULUAN}

Salah satu mikroba penghasil senyawa bioaktif adalah jamur endofit yang merupakan jamur yang tumbuh dan mengkolonisasi di jaringan tumbuhan (inang) terutama di bagian akar, batang dan daun. Jamur endofit dapat menghasilkan senyawasenyawa bioaktif dan metabolit sekunder yang sama dengan inangnya. Kemampuan mikroba endofit dalam menghasilkan senyawa bioaktif merupakan hal yang sangat potensial untuk dikembangkan menjadi obat herbal. Hal ini karena mikroba endofit merupakan mikroorganisme yang mudah ditumbuhkan, memiliki siklus hidup yang pendek dan dapat menghasilkan jumlah senyawa bioaktif dalam jumlah besar dengan metode fermentasi. ${ }^{1}$

Tanaman dapat menjadi sumber untuk menemukan obat baru. Tanaman dikenal memiliki berbagai macam kegunaan dalam mencegah dan mengobati penyakit. Tanaman adalah sumber yang baik untuk sumber berbagai macam bentuk senyawa metabolit sekunder penting seperti fenolik, glikosida, saponin, flavonoid, steroid, tanin, alkaloid dan terpenoid. ${ }^{2}$

Salah satu tanaman yang biasa digunakan masyarakat sebagai bahan obat adalah sesuru (Euphorbia antiquorum L.). Batang sesuru (Euphorbia antiquorum L.) digunakan untuk mengobati diare, bisul, malaria, demam, sakit gigi, rematik, dan sembelit. $^{3}$

Hasil penelitian oleh Arifin B, 2005 bahwa ekstrak etanol batang sesuru telah dapat menghambat pertumbuhan bakteri Staphylococus aureus dengan baik pada konsentrasi $0,5 \%$ sedangkan ekstrak n-butanol 
Isolasi Dan Identifikasi Fungi Endofit Batang Sesuru (Euphorbia antiquorum L.) Sebagai Penghasil Antibakteri Dengan Metode KLT-Bioautografi

pada konsentrasi $2 \%$, ekstrak etanol batang sesuru juga dapat menghambat bakteri Escherichia coli dengan baik pada konsentrasi $0,5 \%$ dan untuk ekstrak n-butanol juga pada konsentrasi $0,5 \%$ dan untuk ekstrak etanol batang sesuru juga dapat menghambat Candida albicans pada konsentrasi $1 \%$ untuk ekstrak n-butanol juga pada konsentrasi $1 \%{ }^{4}$ Oleh karena itu perlunya dilakukan penelitian tentang isolasi dan idenfikasi fungi endofit dari batang sesuru (Euphorbia antiquorum L.) sebagai penghasil antibakteri secara KLTBioautografi.

\section{METODE PENELITIAN}

Alat yang digunakan pada penelitian ini adalah auoklaf (SMIC Model YX-280 B), cawan petri (Normax), gelas erlenmeyer 250 dan $500 \mathrm{~mL}$ (Iwaki Pyrex), gelas kimia 250 dan $500 \mathrm{~mL}$ (Iwaki Pyrex), inkubator (Memmert), lampu spiritus, lampu UV 254 dan 366 nm (Philips), oven (Memmert), shaker, timbangan analitik (Chyo), chamber. Bahan yang digunakan pada penelitian ini adalah aquadest steril, etanol $70 \%$, lempeng $\mathrm{KLT}$, etil asetat, $\mathrm{n}$ heksan, larutan $\mathrm{NaCl}$ 0,9\%, medium Nutrien Agar (NA), medium Potato Dextrosa Agar (PDA), Maltosa Yeast Broth (MYB), Kloramfenikol, bakteri Escherichia coli, Staphylococcus aureus, dan sampel batang sesuru (Euphorbia antiquorum L.)

\section{Prosedur Penelitian}

\section{Penyiapan sampel}

Batang sesuru (Euphorbia antiquorum L.) di ambil dan di sortasi dengan cara dicuci dengan air mengalir hingga bersih kemudian direndam kurang lebih 1 menit dengan menggunakan etanol $70 \%$, dibilas dengan menggunakan aquadest steril, kemudian sampel dipotong-potong kecil-kecil $\pm 1 \mathrm{~cm} .^{5}$

\section{Isolasi fungi endofit dari batang sesuru (Euphorbia antiquorum L.)}

Batang sesuru (Euphorbia antiquorum L.) yang telah dipotong kecil-kecil menjadi \pm 1 $\mathrm{cm}$ diletakkan diatas medium Potato Dekstrosa Agar Chloramphenicol (PDAC) di dalam cawan petri steril yang kemudian diinkubasi pada suhu $25^{\circ} \mathrm{C}-30^{\circ} \mathrm{C}$ selama 3 hari. Setelah 3 hari fungi yang tumbuh, kemudian diisolasi dan dimurnikan pada medium Potato Dekstrosa Agar (PDA) yang baru. Selama pekerjaan dilakukan secara aseptis didalam Laminar Air Flow (LAF). ${ }^{6}$

\section{Pemurnian isolat fungi endofit}

Permurnian dilakukan dengan cara pemindahan masing-masing isolat fungi endofit yang tumbuh ke media Potato Dekstrosa Agar (PDA) yang baru, kemudian diinkubasi selama 3-5 hari pada suhu kamar. Pemurnian dilakukan sampai di peroleh isolat fungi murni yang tunggal dan dilakukan analisis secara makroskopik untuk membedakan isolat fungi yang murni. Pemeriksaan makroskopiknya meliputi permukaan koloni, bentuk koloni, tepi, dan sudut evalensinya (7)

\section{Penyiapan bakteri uji}

Pembuatan stok dan peremajaan bakteri uji

Pembuatan stok dan peremajaan bakteri uji dilakukan dengan mengambil 1 ose biakan bakteri murni kemudian digoreskan diatas permukaan medium Nutrien Agar (NA) miring, kemudian diinkubasi pada suhu $37^{\circ} \mathrm{C}$ selama $1 \times 24$ jam. $^{8}$

\section{Pembuatan suspensi bakteri \\ Bakteri uji hasil peremajaan disuspensikan menggunakan larutan $\mathrm{NaCl}$ fisiologis 0,9\% kemudian diukur kekeruhannya menggunakan spektrofotometer hingga diperoleh nilai tingkat kekeruhan 25\% T pada}


Isolasi Dan Identifikasi Fungi Endofit Batang Sesuru (Euphorbia antiquorum L.) Sebagai Penghasil Antibakteri Dengan Metode KLT-Bioautografi

panjang gelombang $580 \mathrm{~mm}$ yang akan

digunakan dalam uji antibakteri. ${ }^{9}$

\section{Uji skrining aktivitas antibakteri}

Isolat fungi endofit diinokulasikan ke dalam cawan petri yang berisi medium Nutrient Agar (NA) sebanyak $10 \mathrm{~mL}$ yang masingmasing telah diinokulasikan dengan suspensi bakteri uji yaitu Escherichia coli dan Escherichia coli dan Staphylococcus aureus sebanyak $0,2 \mathrm{~mL}(20 \mu \mathrm{L})$ dimana isolat tersebut diletakkan di atas permukaan medium. Kemudian diinkubasi selama 1 x 24 jam pada suhu $37^{\circ} \mathrm{C}$ lalu diamati zona hambat yang terbentuk. ${ }^{5}$

\section{Fermentasi dan ekstraksi}

Isolat aktif kemudian diinokulasi dengan menggunakan ose dan dimasukkan ke dalam labu erlenmeyer yang berisi $100 \mathrm{~mL}$ medium cair Maltosa Yeast Broth (MYB), selanjutnya dilakukan fermentasi menggunakan Rotary shaker dengan kecepatan 200 rpm pada suhu ruang selama 14 hari. Hasil dari fermentasi diperoleh supernatan dan miselia yang disaring menggunakan kertas saring kemudian diambil supernatannya dan diekstraksi dengan metode ekstraksi cair-cair menggunakan etil asetat kemudian diuapkan dengan rotavapor hingga diperoleh ekstrak kental. ${ }^{5}$

\section{Identifikasi secara kromatografi lapis tipis} (KLT)

Ekstrak kental fermentat isolat fungi diidentifikasi secara Kromatografi Lapis Tipis $(K L T)$ dengan menggunakan eluen yang sesuai. Ekstrak ditotolkan pada lempeng KLT dengan menggunakan pipa kapiler. Kromatogram yang dihasilkan di amati di bawah Lampu UV pada panjang gelombang $254 \mathrm{~nm}$ dan $366 \mathrm{~nm}$ diberi tanda dan dihitung nila Rf-nya. ${ }^{5}$

\section{Pengujian secara KLT-Bioautografi}

Medium Nutrien Agar (NA) steril yang telah didinginkan sebanyak $10 \mathrm{ml}$ diinokulasikan dengan bakteri yang peka sebanyak $0.5 \mathrm{ml}$ dan dituang ke dalam cawan petri steril dan dilakukan secara aseptis. Setelah medium agak memadat, lempeng KLT yang telah dielusi diletakkan diatas permukaan medium agar. Setelah 30 menit, lempeng tersebut dipindahkan. Cawan petri kemudian diinkubasi pada suhu $37^{\circ} \mathrm{C}$ selama 24 jam. ZoNa hambatan akan terlihat pada medium agar, dan dibandingkan dengan kromatogram hasil pengujian KLT. ${ }^{10}$

\section{Pengumpulan Data Dan Analisis Data}

Data yang diperoleh dari hasil penelitian dilakukan pengumpulan data berdasarkan hasil isolasi fungi endofit, skrining aktivitas antibakteri, pengujian aktivitas antibakteri secara KLT Bioautografi dan identifikasi golongan komponen kimia aktif dianalisis berdasarkan aktivitas antibakteri isolat fungi endofit batang sesuru (Euphorbia antiquorum L.) yang dapat menghambat pertumbuhan bakteri uji. ${ }^{11}$

\section{HASIL PENELITIAN}

Penelitian ini dilakukan pengujian aktivitas antibakteri dari isolat fungi endofit batang sesuru (Euphorbia antiquorum L.) dengan menggunakan metode KLTBioautografi, dimana diketahui bahwa pengujian aktivitas antibakteri merupakan suatu metode yang digunakan untuk melihat potensi suatu senyawa yang dapat memberikan efek sebagai antibakteri bagi mikroorganisme. Sampel yang digunakan pada penelitian ini yaitu fungi endofit batang sesuru (Euphorbia antiquorum L.) .

Isolasi fungi endofit bertujuan untuk memperoleh kultur murni fungi endofit 
Isolasi Dan Identifikasi Fungi Endofit Batang Sesuru (Euphorbia antiquorum L.) Sebagai Penghasil Antibakteri Dengan Metode KLT-Bioautografi

menggunakan medium Potato Dekstrosa Agar

(PDA) yang telah ditambahkan dengan

Kloramfenikol. Penambahan kloramfenikol bertujuan agar yang tumbuh adalah isolat fungi bukan bakteri. Kloramfenikol merupakan salah satu antibiotik berspektrum luas yang dapat menghambat atau membunuh pertumbuhan bakteri Gram positif dan Gram negatif.
Isolat fungi endofit batang sesuru (Euphorbia antiquorum L.) yang diperoleh dimurnikan dengan tujuan untuk memperoleh isolat fungi endofit murni. Isolat murni dilakukan pemeriksaan makroskopik untuk mengetahui bentuk morfologi isolat dengan melihat bentuk koloni, elevasi, tepi dan warna pada isolat murni yang terlah diperoleh dari hasil pemurnian, dapat dilihat pada tabel 1 .

Tabel 1. Hasil pemurnian isolat fungi endofit batang sesuru (Euphorbia antiquorum L.)

\begin{tabular}{ccl}
\hline No & Kode fungi & Biakan murni \\
\hline 1 & IFBS 1 & Isolat fungi 01 \\
2 & IFBS 2 & Isolat fungi 02 \\
3 & IFBS 3 & Isolat fungi 03 \\
4 & IFBS 4 & Isolat fungi 04 \\
5 & IFBS 5 & Isolat fungi 05 \\
6 & IFBS 6 & Isolat fungi 06
\end{tabular}

Keterangan: IFBS 1 : isolat fungi endofit ke-1, IFBS 2 : isolat fungi endofit ke-2, IFBS 3 : Isolat fungi endofit ke-3, IFBS 4 : isolat fungi endofit ke-4, IFBS 5 : isolat fungi endofit ke-5, IFBS 6 : isolat fungi endofit ke-6.

Hasil pemurnian dari batang sesuru (Euphorbia antiquorum L.) diperoleh 6 isolat fungi endofit yang memberikan daya hambat dan bentuk koloni yang berbeda. Isolat fungi endofit yang telah murni kemudian ditentukan karakteristiknya secara makroskopik dengan melihat bentuk morfologi isolat fungi endofit sehingga dapat diketahui perbedaan dan persamaan isolat yang diperoleh berupa bentuk koloni, tepi koloni, elevasi koloni, warna dan struktur koloni dapat dilihat pada tabel 2.

Tabel 2. Hasil pengujian makroskopik isolat fungi endofit batang sesuru (Euphorbia antiquorum L.)

\begin{tabular}{cccccc}
\hline Kode & Bentuk Koloni & Bentuk tepi & $\begin{array}{c}\text { Bentuk } \\
\text { elevasi }\end{array}$ & $\begin{array}{c}\text { Keadaan } \\
\text { permukaan }\end{array}$ & $\begin{array}{c}\text { Warna depan/ } \\
\text { belakang }\end{array}$ \\
\hline IFBS 1 & $\begin{array}{c}\text { Concentric } \\
\text { (konsentris) }\end{array}$ & $\begin{array}{c}\text { Ciliate } \\
\text { (siliat) }\end{array}$ & $\begin{array}{c}\text { Raised } \\
\text { (timbul) }\end{array}$ & Beludru & $\begin{array}{c}\text { Abu-abu kecoklatan } \\
\text { /Hitam kehijauan }\end{array}$ \\
\hline IFBS 2 & $\begin{array}{c}\text { Round with } \\
\text { scalloped } \\
\text { margin } \\
\text { (bundar dengan } \\
\text { tepian kerang) }\end{array}$ & $\begin{array}{c}\text { Smooth } \\
\text { (entire) } \\
\text { (licin) }\end{array}$ & $\begin{array}{c}\text { Flat } \\
\text { (datar) }\end{array}$ & beludru & $\begin{array}{c}\text { Coklat pinggiran } \\
\text { putih/Hijau tua }\end{array}$ \\
\hline IFBS 3 & $\begin{array}{c}\text { Irregular and } \\
\text { spreading } \\
\text { (tidak teratur } \\
\text { dan menyebar) }\end{array}$ & $\begin{array}{c}\text { lobate } \\
\text { (berlekuk) }\end{array}$ & $\begin{array}{c}\text { Flat } \\
\text { (datar) }\end{array}$ & berlendir & $\begin{array}{c}\text { Putih bening /putih } \\
\text { bening }\end{array}$ \\
\hline IFBS 4 & $\begin{array}{c}\text { Round with } \\
\text { scalloped } \\
\text { margin( bundar } \\
\text { dengan tepian } \\
\text { kerang) }\end{array}$ & $\begin{array}{c}\text { wooly } \\
\text { (seperti wol) }\end{array}$ & $\begin{array}{c}\text { Crateriform } \\
\text { (seperti } \\
\text { kawah) }\end{array}$ & beludru & $\begin{array}{c}\text { Putih/kuning } \\
\text { kecoklatan }\end{array}$ \\
\hline IFBS 5 & $\begin{array}{c}\text { Round with } \\
\text { radlating margin }\end{array}$ & $\begin{array}{c}\text { Branching } \\
\text { smooth }\end{array}$ & $\begin{array}{c}\text { Flat } \\
\text { (datar) }\end{array}$ & Kapas & $\begin{array}{c}\text { Putih kecoklatan/ } \\
\text { Coklat keputihan }\end{array}$ \\
\hline
\end{tabular}


Isolasi Dan Identifikasi Fungi Endofit Batang Sesuru (Euphorbia antiquorum L.) Sebagai Penghasil Antibakteri Dengan Metode KLT-Bioautografi

\begin{tabular}{|c|c|c|c|c|c|}
\hline Kode & Bentuk Koloni & Bentuk tepi & $\begin{array}{l}\text { Bentuk } \\
\text { elevasi }\end{array}$ & $\begin{array}{l}\text { Keadaan } \\
\text { permukaan }\end{array}$ & $\begin{array}{l}\text { Warna depan/ } \\
\text { belakang }\end{array}$ \\
\hline & $\begin{array}{c}\text { (bundar dengan } \\
\text { tepian } \\
\text { menyebar) }\end{array}$ & $\begin{array}{c}\text { (bercabang } \\
\text { halus) }\end{array}$ & & & \\
\hline IFBS 6 & $\begin{array}{l}\text { Round with } \\
\text { scalloped } \\
\text { margin } \\
\text { (bundar dengan } \\
\text { tepian kerang) }\end{array}$ & $\begin{array}{l}\text { Smooth } \\
\text { (entire) } \\
\text { (licin) }\end{array}$ & $\begin{array}{l}\text { convex } \\
\text { (cembung) }\end{array}$ & berlendir & $\begin{array}{l}\text { Kuning pinggiran } \\
\text { putih /Kuning }\end{array}$ \\
\hline \multicolumn{6}{|c|}{$\begin{array}{l}\text { Keterangan: IFBS } 1 \text { : isolat fungi endofit ke-1, IFBS } 2: \text { isolat fungi endofit ke-2, IFBS } 3: \text { Isolat fungi endofit ke-3, IFBS } 4 \text { : isolat } \\
\text { fungi endofit ke-4, IFBS } 5: \text { isolat fungi endofit ke-5, IFBS } 6: \text { isolat fungi endofit ke-6. }\end{array}$} \\
\hline \multicolumn{3}{|c|}{$\begin{array}{l}\text { Hasil pengujian skrining isolate fungi } \\
\text { endofit batang sesuru (Euphorbia antiquorum }\end{array}$} & \multicolumn{3}{|c|}{$\begin{array}{l}\text { bakteri uji dengan diameter zona hambat } \\
\text { terbesar pada isolat fungi endofit dengan } \\
\text { kode IFBS03 dan IFBS06, dapat dilihat pada }\end{array}$} \\
\hline
\end{tabular}
fungi endefit memberikan aktivitas terhadap

Tabel 3. Hasil pengujian skrining isolat fungi endofit batang sesuru (Euphorbia antiquorum L.)

\begin{tabular}{ccc}
\hline Kode isolate & Staphylococcus aureus & Escherichia coli \\
\hline IFBS 1 & 10,12 & 9.21 \\
IFBS 2 & 9.10 & 7,20 \\
IFBS 3 & 14,90 & 11.23 \\
IFBS 4 & 11,60 & 10.37 \\
IFBS 5 & 7,26 & 8.28 \\
IFBS 6 & 18,67 & 13.28
\end{tabular}

Keterangan: IFBS 1 : isolat fungi endofit ke-1, IFBS 2 : isolat fungi endofit ke-2, IFBS 3 : Isolat fungi endofit ke-3, IFBS 4 : isolat fungi endofit ke-4, IFBS 5 : isolat fungi endofit ke-5, IFBS 6 : isolat fungi endofit ke-6.

Isolat fungi endofit kode IFBS-03 memberikan aktivitas yang paling baik terhadap bakteri Staphylococcus aureus dengan diameter hambatan $14,90 \mathrm{~mm}$ dan Escherichia coli dengan diameter hambatan 11,23 mm masuk dalam kategori sedang dan untuk IFBS-06 memberikan aktivitas yang paling baik terhadap bakteri Staphylococcus aureus dengan diameter hambatan 18,16 mm dan Escherichia coli dengan diameter hambatan 13,20 mm masuk dalam kategori kuat yang dibandingkan dengan literatur menurut Mulyani, 2013. Respon hambatan pertumbuhan bakteri dapat diklasifikasikan sebagai berikut diameter hambatan $>20 \mathrm{~mm}$ dikategorikan sangat kuat, diameter hambatan 16-20 mm dikategorikan kuat, diameter hambatan 10-15 $\mathrm{mm}$ dikategorikan sedang dan diameter hambatan $<10 \mathrm{~mm}$ dikategorikan lemah. Hal inilah yang mendasari pemilihan isolat fungi endofit dengan kode IFBS-03 dan IFBS-06 yang diteliti lebih lanjut potensinya sebagai antibakteri secara KLTBioautografi.

Secara KLT-Bioautografi fermentat supernatant dengan kode IFBS-03 diperoleh nilai $\operatorname{Rf} 0,87$ dan 0,27 aktif terhadap bakteri Staphylococcus aureus, dan Escherichia coli. Sedangkan fermentat supernatant dengan kode IFBS-06 diperoleh nilai $\mathrm{Rf}$ 0,83 aktif terhadap bakteri Staphylococcus aureus, nilai Rf 0,83 dan 0,27 aktif terhadap bakteri Escherichia coli dan hasil identifikasi golongan komponen kimia ekstrak etil asetat isolate IFBS-03 dan IFBS-06 menggunakan perekasi kimia antimo (III) klorida menunjukkan adanya golongan flavonoid, dapat dilihat pada tabel 4 . 
Tabel 4. Hasil pengujian KLT bioautografi dari kromatogram ekstrak etil asetat batang sesuru (Euphorbia antiquorum L.) dengan menggunakan eluen etil asetat : metanol $(8: 1)$

\begin{tabular}{|c|c|c|c|c|c|}
\hline \multirow{2}{*}{ Isolat } & \multirow{2}{*}{ Rf } & \multicolumn{2}{|c|}{ Warna pada penampak bercak } & \multirow{2}{*}{ Bakteri } & \multirow{2}{*}{$\begin{array}{c}\text { Antimo (III) } \\
\text { KIrorida }\end{array}$} \\
\hline & & UV 254 nm & UV 366 nm & & \\
\hline \multirow{2}{*}{ IFBS 3} & $\begin{array}{l}0,87 \\
0,27\end{array}$ & Hijau & Biru & $E C$ & \multirow{2}{*}{ Kuning (+) } \\
\hline & $\begin{array}{l}0,87 \\
0,27\end{array}$ & Hijau & Biru & $S A$ & \\
\hline \multirow{2}{*}{ IFBS 6} & $\begin{array}{l}0,83 \\
0,27 \\
\end{array}$ & Hijau & Biru & $E C$ & \multirow{2}{*}{ Kuning $(+)$} \\
\hline & 0,83 & Hijau & Biru & $S A$ & \\
\hline
\end{tabular}

Keterangan: SA : staphylococcus aureus, EC: Escherichia coli

\section{KESIMPULAN}

Berdasrkan hasil penelitian

disimpulkan bahwa fungi endofit dari batang sesuru (Euphorbia antiquorum L.) memiliki aktivitas antibakteri terhadap Staphylococcus aureus, dan Escherichia coli. Profil kromatogram aktivitas fermentat isolate IFBS06 dengan nilai $\operatorname{Rf} 0,83$ aktif terhadap bakteri Staphylococcus aureus, nilai Rf 0,83 dan 0,27 aktif terhadap bakteri Escherichia coli menunjukkan adanya golongan flavonoid menggunakan pereaksi Antimo (III) klorida.

\section{DAFTAR PUSTAKA}

1. Yasir Y, Yuniati $Y$, Paramita S, Zubaidah M, Mu'ti A, Danial D. Analisis bioautografi dengan kromatografi lapis tipis pada ekstrak etanol daun Caesalpinia sumatrana roxb. Terhadap bakteri penyebab infeksi nosokomial. Jurnal Sains Dan Kesehatan. 2017; 1(7): 359-366.

2. Radji M. Peranan Bioteknologi dan Mikroba Endofit dalam Pengembangan Obat Herbal. Majalah IImu Kefarmasian. 2015; 2(3): 113-126.

3. Dalimartha S. Atlas Tumbuhan Obat Indonesia Jilid 3. Jakarta. Puspa Swara; 2003.

4. Arifin B. Uji Aktivitas Antimikroba Ekstrak Eter dan N-Butanol Batang sesuru (Euphorbia antiquorum L.) Terhadap Beberapa Mikroba Uji (Skripsi). Makassar. Universitas Muslim Indonesia, Fakultas Farmasi; 2005.
5. Fitriana, Abdullah AS, Achmar A. Profil Bioautogram Ekstrak Fermentat Isolate Fungi Endofit Dari Daun Galing-Galing (Cayratia trifolia) sebagai antibakteri. AsSyifaa Jurnal Farmasi. 2019; 11(1): 17-23.

6. Fitriana, Nursithya E. Aktivitas Antibakteri Ekstrak Isolat Fungi Endofit Dari Akar Mangrove (Rhizophora apiculata Blume) Secara KLT Bioautografi. As-Syifaa Jurnal Farmasi. 2017; 9(1): 27-36.

7. Elviasari J, Rolan R, Adam M, Ramadhan. Isolasi Jamur Endofit Daun Beluntas (Pluchea indica (L.) Less). Jurnal Sains dan Kesehatan. 2015; 1(3): 127.

8. Litaay M, Sari K, Gobel RB, Haedar N. Potensi Abalon Tropis Haliotis asinina L. sebagai Sumber Inokulum. Spermonde. 2017; 3(1): 42-46.

9. Fitriani $Y$, Husain D, Hasyim A, Abdullah A. Kemampuan Beberapa Isolat Bakteri Endosimbion Cacing Tanah Pheretima sp dalam Menghambat Pertumbuhan Bakteri Salmonella thypi dan Staphylococcus aureus (Skripsi). Makassar: Universitas Hasanuddin; 2016.

10. Djide N, Sartini, Kadir S. Analisis Mikrobiologi Makassar. Makassar. Laboratorium Mikrobiologi Fakultas Matematika Dan IImu Pengetahuan Alam, Universitas Hasanuddin; 2006.

11. Herwin. Isolasi Fungi Endofit Penghasil Antibiotika Pada Alga Merah Jenis Gracilaria Verrucosa Secara KLTBioautografi. As-Syifaa Jurnal Farmasi. 2018; 10(1): 85-86. 